\title{
Quantitative PCR for Hepatitis B Virus with Colorimetric Detection
}

\author{
Päivi Lehtovaara, Mikko Uusi-Oukari, ${ }^{1}$ Petri Buchert, Matti Laaksonen, Marina Bengtström, \\ and Marjut Ranki
}

Orion Corporation, Orion Pharmaceutica, Biotechnology, SF-02101 Espoo, Finland

\begin{abstract}
A novel, sensitive colorimetric test is described for quantification of the initial number of hepatitis $B$ virus (HBV) genomes amplified in PCR. The viral genomes are amplified together with a synthetic internal standard (IS) to correct for the variability of the efficiency factor. One of the two primers is blotinylated, and the amplified mixtures of $\mathrm{HBV}$ and is DNAs are bound to streptavidincoated microtiter plates for quantitative detection. The ratio of HBV to IS DNA is determined for each sample by hybridization with DNP-containing probes and immunoenzymatic detection. The colorimetric detection is quantitative, rapid, and accurate with a dynamic range from $\sim 10^{8}$ to $>10^{11}$ DNA molecules. The initial number of HBV genomes in a clinical sample is interpreted from the signal ratio $\mathrm{HBV} / \mathrm{IS}$ by using a standard curve, obtained from coamplification of known quantities of synthetic HBV templates with IS. The assay quantified 15 viral genomes from $10 \mu \mathrm{l}$ of serum, and its dynamic range was up to five orders of magnitude. After the amplification step, the assay takes $<2 \mathrm{hr}$, and the method is applicable to automation.
\end{abstract}

'Present address: National Public Health Institute, Mannerheimintie 166,00300 Helsinki, Finland. he in vitro DNA amplification methods are restricted primarily to qualitative analyses, including the "semiquantitative PCR assays." (1) There would be need for validated quantitative assays, especially if they were simple enough for routine diagnostic use. We describe here a practical, rapid, and sensitive nonradioactive method for quantification of the initial number of hepatitis $B$ virus (HBV) templates from clinical samples. The method is principally applicable to any DNA.

In PCR the amount of amplified material is $N=N_{\mathrm{o}}(1+e f f)^{n}$, where $N_{\mathrm{o}}$ is the initial amount of template, eff is the efficiency, and $n$ is the number of cycles. The efficiency of amplification varies from sample to sample and also decreases during cycling. The estimation of the initial quantity of template has been considered difficult because the efficiency factor may be decreased, especially in clinical samples, depending on their quality. Some PCR inhibitors from serum may not be removed completely, and reagents used in pretreatment can be inhibitory. False-negative results may occur without proper standardization. Moreover, the reproducibility of releasing the DNA from the clinical specimen is an important factor affecting the result. In the present test, quantification is based on coamplification with an internal standard, which has been applied to eliminate sample-dependent variation in amplification efficiency. ${ }^{(2-8)}$ We have described earlier the principle of coamplification in the form a prototype test. $^{(9)}$

Qualitative PCR for HBV DNA has been described frequently, ${ }^{(10-13)}$ and the sensitivity of PCR tests has been shown to be at least as good as that of infectivity testings with chimpanzees. ${ }^{(14)}$ A quantitative PCR assay, capable of monitoring HBV DNA levels at higher sensitivity than present tests, would be required for assessing the efficacy of antiviral therapy. ${ }^{(12,15-17)}$ A sensitive and quantitative test would also be useful in assessing potential infectivity of problematic cases of donated blood units ${ }^{(18)}$ and for assessing whether asymptomatic chronic carriers are contagious.

\section{MATERIALS AND METHODS}

DNA Standards, Respective Primers, and Probes

The HBV DNA standard template was synthesized using an Applied Biosystems 381 A Synthesizer. It contained the 104bp long sequence 1864-1967 from the pre- $C$ and $C$ gene region of $\mathrm{HBV}$ genome of subtype ayw. ${ }^{(19)}$ The synthetic internal standard (IS) DNA was a mutant version of the former, in that the 21-mer internal sequence was replaced by an unrelated sequence. The molecular concentrations of the purified DNAs were determined by spectrophotometry. The primers used were 5 -biotin-GTT CAI GCC TCC AAG CTG TG and 5'-TCA GAA GGC AAA AAI GAG AGT AAC T (I is inosine). These primers were amplifying DNA from the $C$ and pre- $C$ region of the HBV genome ${ }^{(19)}$ and were obtained from MedProbe A.S. (Oslo, Norway).

In the reference amplification system 2 , longer and nonhomologous competing DNAs were amplified. ${ }^{(9)}$ The HBV and IS sequences in this system were amplified with common primers and were recognized by the probes used in the test. The standard plasmid DNAs were linearized. The primers for the reference amplification system were $5^{\prime}-B_{2-4}$ TTC 
AAG CCT CCA AGC TGT GCC T (which is overlapping with the biotinylated primer above), and 5'-GTT AGC GGC GCA GCG TCT. ${ }^{(20)}$ Here, B was a biotinylated $C$ added to the oligonucleotide in an Applied Biosystems A 381 synthesizer using the respective phosphoramidite reagent (M. Bengtström, L. Paulin, and B. Sproat, unpubl.).

The detection probe for HBV DNA (5'CTT TAT AAG GAT CAA TGT CCA TGC) was modified with a dinitrophenyl (DNP) group at the 5' and 3 ' ends. Also a probe with three DNP groups at the $5^{\prime}$ end was used (British Biotechnology, Abingdon, Oxon, UK). The detection probe for IS DNA was similarly labeled.

\section{Clinical Samples}

Patient sera were obtained from the Department of Virology, University of Helsinki, Finland. Negative control serum was from the Finnish Red Cross. All samples were also tested with the commercial quantitative AffiProbe HepB test for HBV DNA (Sangtec Medical, Bromma, Sweden). A HBV-positive reference plasma (see ref. 1, genotype A) analyzed in the Eurohep standardization project (21) was obtained from W.H. Gerlich (University of Giessen, Germany).

For the quantitative PCR, serum was pretrated by precipitation with polyethylene glycol followed by lysis with $\mathrm{NaOH}$, neutralization, boiling, and centrifugation. An aliquot of the supernatant corresponding to $10-40 \mu \mathrm{l}$ of original serum was subjected to amplification by PCR (M. Uusi-Oukari, A. KähäräUppgård, M. Ranki, and P. Lehtovaara, unpubl.)

\section{Amplification in Competitive PCR}

In addition to HBV DNA, the PCR reaction contained $50 \mathrm{mM}$ Tris- $\mathrm{HCl}(\mathrm{pH} \mathrm{8.8)}$, $1.5 \mathrm{mM} \mathrm{MgCl}_{2}, 15 \mathrm{~mm}\left(\mathrm{NH}_{4}\right)_{2} \mathrm{SO}_{4}, 0.1 \%$ Tween $20,0.2 \mathrm{~mm}$ dNTPs, $0.2 \mu \mathrm{M}$ amplification primers, $10^{3}$ molecules of IS DNA, and 1 unit of Taq polymerase (Promega Corp., Madison, WI) or thermostable DNA polymerase (Dynazyme, Finnzymes, Finland) in a total volume of $100 \mu \mathrm{l}$. The samples were overlaid with two drops of mineral oil. Thirty cycles of amplification (DNA Thermal Cycler, Perkin-Elmer Cetus or PTC-100-60, MJ Research Inc., Watertown, MA) consisted of $30 \mathrm{sec}$ of denaturation at $96^{\circ} \mathrm{C}, 1 \mathrm{~min}$ of primer annealing at $55^{\circ} \mathrm{C}$, and 1 min of primer extension at $72^{\circ} \mathrm{C}$, except that in the first cycle the denaturation step at $96^{\circ} \mathrm{C}$ was extended to $6 \mathrm{~min}$ and the last extension step to $11 \mathrm{~min}$.

\section{Detection on Microtiter Plates}

Each sample was to be hybridized with two different probes (HBV and IS specific, respectively); therefore, 50- $\mu 1$ aliquots from each PCR sample, first diluted $1: 4$, were pipetted to microtiter plate wells coated with streptavidin (see
Fig. 1; HepB sensitive test kit, Sangtec Medical, Bromma, Sweden). Two parallel hybridizations were usually performed. The plate was shaken for $15 \mathrm{~min}$ at room temperature in a plate shaker. Fifty microliters of $100 \mathrm{~mm} \mathrm{NaOH}$ and $300 \mathrm{~mm}$ $\mathrm{NaCl}$ were added to the wells and, after shaking for $1 \mathrm{~min}$, the plates were washed three times with $25 \mathrm{~mm}$ Tris- $\mathrm{HCl}$ ( $\mathrm{pH} 7.5$ ), $125 \mathrm{~mm} \mathrm{NaCl}, 2 \mathrm{~mm} \mathrm{MgCl}$, and $0.3 \%$ Tween in a microtiter plate washer. The HBV- or IS-specific DNP probe was added at a concentration of $10^{12}$ molecules per well, and hybridization oc-
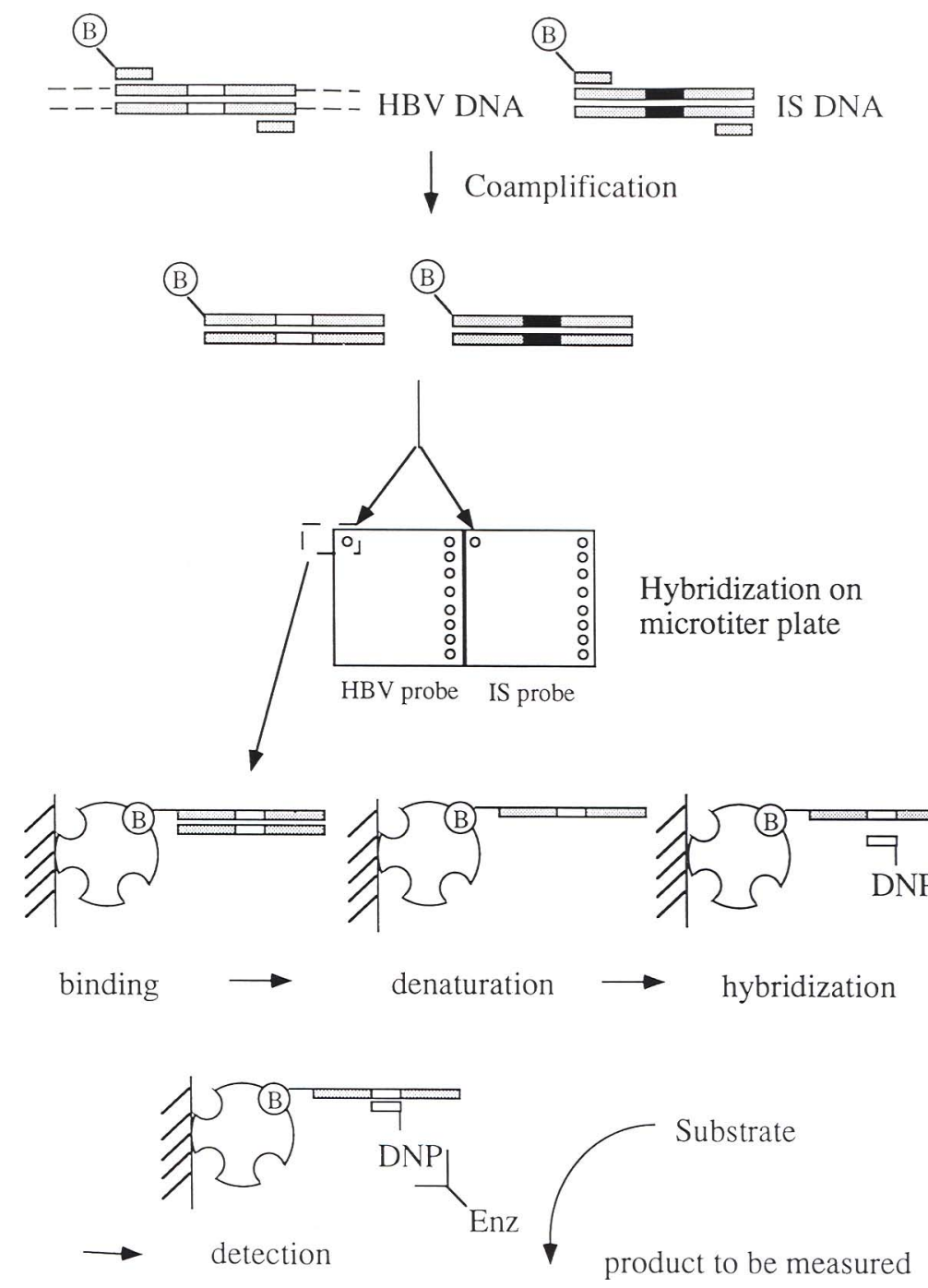

FIGURE 1 Principle of the quantification assay for HBV DNA. The assay includes (1) Competitive amplification of 104-bp-long HBV DNA and IS DNA sequences using common primers (one of which is biotinylated). The IS sequence is designed to differ from the amplified HBV sequence only in the 21-mer region shown in black. (2) Binding of the biotinylated DNAs to the streptavidin-coated microtiter plate. Each sample is to be detected with two different probes. (3) Removal of the nonbiotinylated strands and hybridization with DNP-labeled HBV and IS-specific oligonucleotides, respectively. (4) Colorimetric immunoenzymatic detection of the hybridized probes, giving numerical quantitative results for HBV DNA and IS DNA content in each sample. The signal ratio HBV/IS is calculated. 
curred at room temperature for $15 \mathrm{~min}$ with shaking.

The plate was washed six times and anti-DNP-alkaline phosphatase conjugate was added [ $50 \mu \mathrm{l}$ of $25 \mathrm{~mm}$ HEPES (pH 7.5), $125 \mathrm{~mm} \mathrm{NaCl}, 2 \mathrm{mM} \mathrm{MgCl}_{2}, 1 \%$ BSA, and $0.3 \%$ Tween]. After the plate was shaken at room temperature for 15 min, it was washed six times, and the substrate $p$-nitrophenyl phosphate (pNPP) was added as $4 \mathrm{mg} / \mathrm{ml}$ of solution in standard diethanolamine- $\mathrm{MgCl}_{2}$ buffer in a volume of $100 \mu$ l. The reaction was allowed to proceed at room temperature with shaking, and the plate was read spectrophotometrically at 405 nm (Multiscan Plus plate reader, Labsystems, Helsinki, Finland) after suitable time intervals (e.g., 4, 10, $30 \mathrm{~min}$ ).

\section{RESULTS}

\section{Outline of the Assay}

The substance of the assay is illustrated in Figure 1. The clinical sample is pretreated to release the viral genome quantitatively, and an aliquot corresponding to $10 \mu \mathrm{l}$ (up to $50 \mu \mathrm{l}$ ) of serum is subjected to PCR amplification, together with $10^{3}$ molecules of a synthetic (IS). The IS sequence is identical to the amplified 104-mer sequence of the HBV genome except that it contains an internal 21-mer replacement. Coamplification is continued for 30 cycles.

The amplified HBV and IS DNA, both of which are biotinylated at one 5 ' end, are quantified by binding to streptavidin-coated microtiter plates, removing the nonbiotinylated strands, and hybridizing with an HBV-specific and an IS-specific probe, respectively. The hybridized DNP label is quantified in an immunoenzymatic reaction, and the ratio of the HBV- and IS-specific signals is determined. The initial quantity of the HBV genome is interpreted from a standard curve.

\section{The Standard Curve}

To obtain the standard curve (Fig. 2), known numbers of molecules of the synthetic HBV standard template (usually $10^{2}-10^{6}$ molecules) were coamplified with $10^{3}$ molecules of IS. The signal ratios of HBV/S were determined and plotted against the initial number of $\mathrm{HBV}$ DNA molecules in a logarithmic scale. If the two competing templates were am-

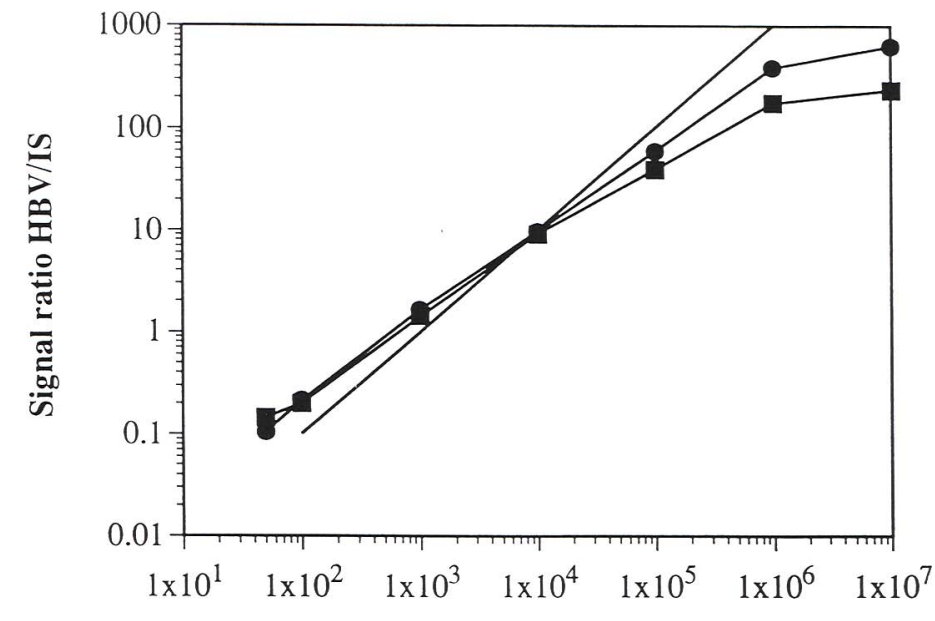

Molecules of HBV DNA standard before amplification

FIGURE 2 Competitive amplification of HBV DNA and IS DNA: the standard curve for the assay with 104-bp long synthetic templates with $80 \%$ homology ( ) and from the reference amplification system $2(\boldsymbol{\square})$. The initial number of IS DNA molecules was always $10^{3}$. The two standard curves were each a mean of three to four individual experiments. The third linear curve is theoretical, assuming an identical amplification efficiency for HBV and IS DNA at all combinations.

plified with an identical amplification efficiency, and the initial ratio of the templates would not affect the efficiency, it would be possible to calculate the results directly (see theoretical curve, Fig. 2). The ratio of HBV/IS after amplification would be multiplied by the known initial quantity of IS, as the ratio would remain constant. However, the slope of the experimental curve in Figure 2 , obtained by coamplifying the synthetic 104-bp standards, was less steep than that of the theoretical slope. Also dilution series of the authentic viral genome showed results similar to those from the synthetic template. Thus, the initial ratio of the two templates had some effect on the amplification efficiency, which had to be corrected by using a standard curve. The experimental standard curve established the correlation between the signal ratio HBV/IS and the initial quantity of $\mathrm{HBV}$ DNA over four to five orders of magnitude.

The synthetic 104-bp-long HBV and IS DNA standards were designed to have a high degree of homology ( $80 \%$ of the sequences were identical), because it has been generally assumed that the sequence of a competing IS ought to be as homologous as possible to the target DNA. ${ }^{(4,22)}$ We also studied the performance of the assay with an IS template totally unrelated to the HBV template except at the common primer regions (amplification system 2) (Fig. 2). Interest- ingly, the competition among highly homologous DNAs and the competition of unrelated longer sequences gave almost indistinguishable results for the standard curves. The only minor differences were that the linear range was reproducibly larger and the efficiency was better with the homologous standards, which were amplified as shorter fragments. Both amplification systems can, in principle, be used in the quantitative test.

\section{Validation of Quantitative Nonradioactive Detection}

The amplified biotinylated products were quantitatively bound to a streptavidin-coated microtiter plate well in 15 min with shaking. The bound DNA was made single stranded with brief alkali treatment before hybridization with single-stranded, DNP-labeled oligonucleotide probe. Quantitative hybridization occurred rapidly, within 5-15 $\mathrm{min}$ at room temperature, depending on the probe concentration (data not shown).

The DNP-labeled hybrids were detected by an anti-DNP-alkaline phosphatase conjugate, which produced a spectrophotometrically measurable product from the pNPP substrate. Because the kinetics of this reaction was linear over $4 \mathrm{hr}$ (Fig. 3), the dynamic range for the colorimetric detection could be expanded by taking advantage 


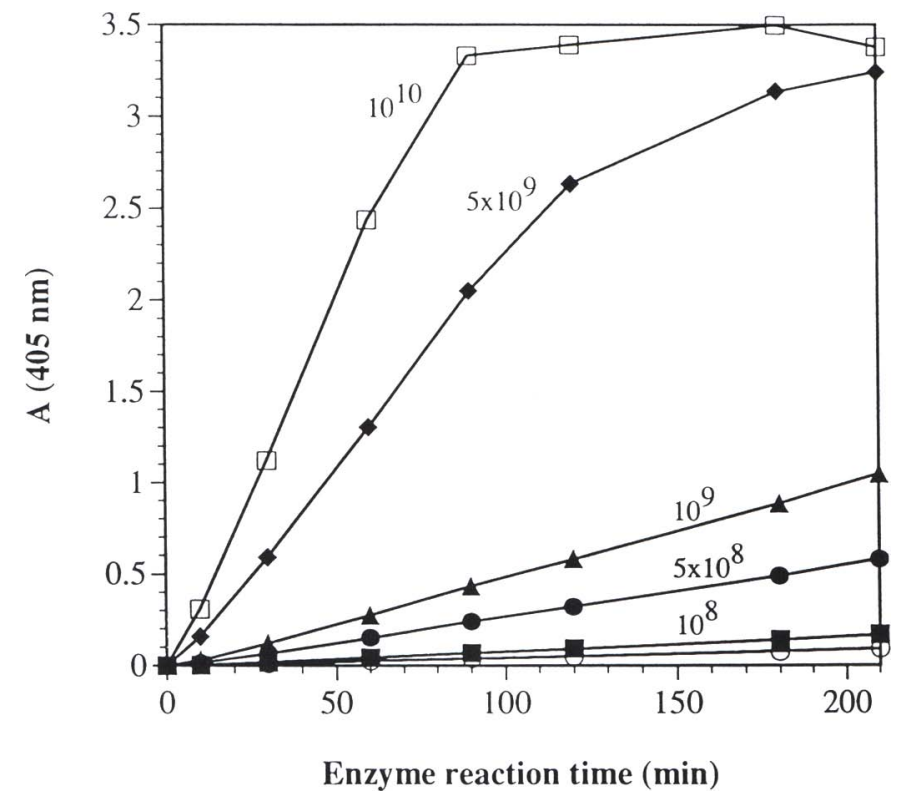

FIGURE 3 Linearity of the enzyme reaction in colorimetric quantification of biotinylated HBV DNA on microtiter plates. Various amounts of purified PCR product (from amplification system 2) were bound to the plate and quantified. Hybridization was with DNP-labeled oligonucleotide containing an average of 1.5 DNP groups, and the hybrids were detected with anti-DNP-alkaline phosphatase conjugate. Formation of the reaction product from the pNPP substrate was followed at $405 \mathrm{~nm}$ at time intervals. The results were a mean of four parallel determinations.

of repeated measurements and extrapolation, for example, routinely measuring the enzyme reaction after 4,10 , and 30 min. It was possible to cover more than three orders of magnitude in this colorimetric measurement: The lowest detectable amount was $\sim 10^{8}$ DNA molecules

(in a 30-min reaction time) and the highest was $>10^{11}$ molecules $(4 \mathrm{~min})$ as shown in Figure 4 . A cutoff value defined as a signal-to-noise ratio of 2 , corresponded to $\sim 2 \times 10^{8}$ molecules of DNA, and defined as the mean of blank values +3 s.D. to $\sim 10^{8}$ molecules (Fig. 4 ).

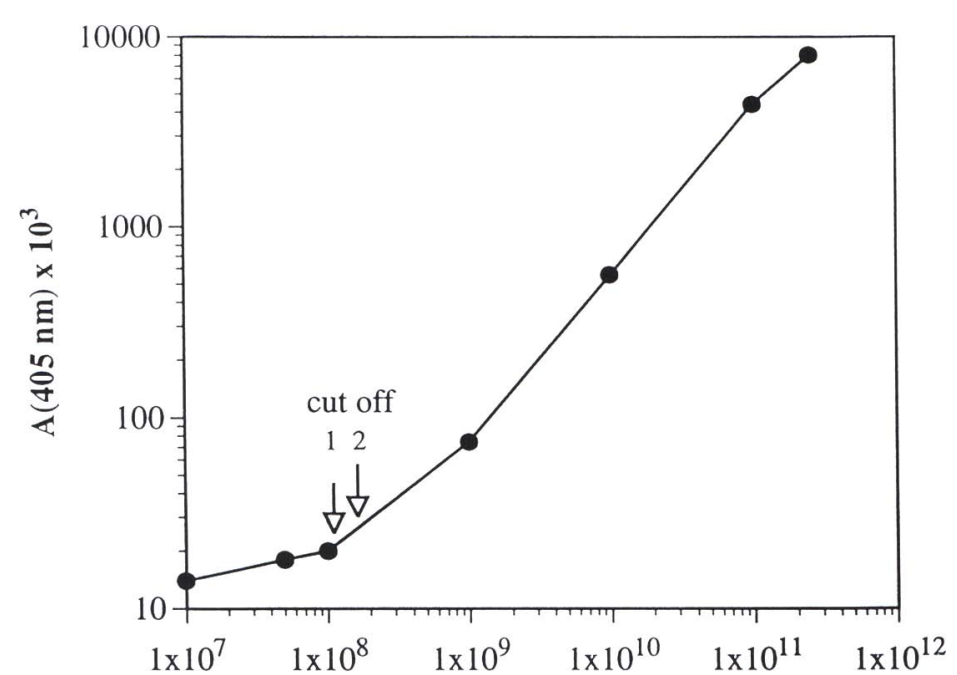

FIGURE 4 The dynamic range of the colorimetric quantification of biotinylated HBV DNA. The amplified 104-bp-long biotinylated HBV DNA was purified, and quantified spectrophotometrically, and different amounts were bound to the microtiter plate in a volume of $50 \mu \mathrm{l}$. The detection probe contained three successive DNP groups at the $5^{\prime}$ end. The cutoff limits 1 and 2 denote the mean of blank readings plus three standard deviations and a signal-to-noise ratio of 2 , respectively.
The detection assay was quantitative and highly reproducible. The coefficient of variation (CV) for the detection step was $3.2 \%$, measured in the experiment shown in Figure 3 with four parallel samples at each point.

\section{Accuracy of Quantification of HBV DNA from Serum Samples}

An important prerequisite for a quantitative PCR assay for HBV DNA is that the specimen pretreatment results in quantitative and reproducible DNA yields from different sera, irrespective of the virus concentration or the quality of the sample. We have developed a pretreatment method that gives quantitative and reproducible yields for viral DNA (M. Uusi-Oukari, A. Kähärä-Uppgård, M. Ranki, and P. Lehtovaara, in prep.).

A reference test for quantification was used to demonstrate the reliability of the quantitative PCR test. The AffiProbe HepB test ${ }^{(23)}$ is a radioactive hybridization assay for nonamplified HBV DNA covering the dynamic range of $5 \times 10^{6}$ -

TABLE 1 Accuracy of Quantification of HBV DNA in Clinical Specimens

\begin{tabular}{|c|c|c|}
\hline \multirow[b]{2}{*}{$\begin{array}{l}\text { Serum } \\
\text { sample }\end{array}$} & \multicolumn{2}{|c|}{$\begin{array}{l}\text { Number of HBV genomes } \\
\text { (in } 10 \mu \mathrm{l} \text { ) }\end{array}$} \\
\hline & expected $^{A}$ & $\begin{array}{l}\text { detected } \\
\text { in the } \\
\text { PCR test }\end{array}$ \\
\hline 1 & $1.2 \times 10^{5}$ & $4.8 \times 10^{5}$ \\
\hline 2 & $1.7 \times 10^{5}$ & $7.0 \times 10^{5}$ \\
\hline 3 & $<5 \times 10^{4}$ & $2.7 \times 10^{3}$ \\
\hline 4 & $2.3 \times 10^{5}$ & $4.1 \times 10^{5}$ \\
\hline 5 & $2.3 \times 10^{5}$ & $1.4 \times 10^{5}$ \\
\hline 6 & $1.2 \times 10^{4}$ & $1.2 \times 10^{4}$ \\
\hline 7 & $6.2 \times 10^{4}$ & $1.9 \times 10^{5}$ \\
\hline 8 & $5.4 \times 10^{4}$ & $3.5 \times 10^{4}$ \\
\hline 9 & $1.0 \times 10^{4}$ & $2.7 \times 10^{4}$ \\
\hline 10 & $3.6 \times 10^{4}$ & $9.0 \times 10^{4}$ \\
\hline 11 & $1.5 \times 10^{4}$ & $2.1 \times 10^{4}$ \\
\hline 12 & $2.3 \times 10^{4}$ & $4.2 \times 10^{4}$ \\
\hline 13 & $2.0 \times 10^{4}$ & $4.0 \times 10^{4}$ \\
\hline 14 & $1.5 \times 10^{4}$ & $1.5 \times 10^{4}$ \\
\hline $15^{\mathrm{b}}$ & $1.4 \times 10^{4}$ & $2.3 \times 10^{4}$ \\
\hline
\end{tabular}

${ }^{a}$ The expected number of molecules is based on the AffiProbe results. The samples (except AffiProbe-negative sample 3) were diluted 1:100 with negative control serum before quantification with the PCR test.

${ }^{\text {b}}$ The undiluted sample 15 was pretreated with the method used for the PCR test before AffiProbe detection. After pretreatment, it was diluted with buffer and quantified with the PCR test using the reference amplification system. 
$5 \times 10^{8}$ viruses $/ \mathrm{ml}$ and starting with 100 $\mu l$ of serum. The AffiProbe pretreatment inhibited the PCR test, but other data obtained (see sample 15, Table 1) suggest that both pretreatment methods were quantitative, and thus allowed the comparison.

Table 1 shows quantification of $\mathrm{HBV}$ genomes from $15 \mathrm{HBsAg}$ - and $\mathrm{HBeAg}$ positive clinical serum samples. The undiluted sera were quantified with the reference test, and the positive samples were diluted $1: 100$ with HBV-negative serum before the PCR test. The quantitative results from the two tests were in good agreement for all samples, demonstrating that the PCR test is reliable and accurate. The consistent, slightly higher titers obtained with the PCR method (on the average of 2.1-fold) presumably were caused by differences in standardization. The results also indicated that the test is not sensitive to strain differences (the viral strains were not known, but the sera were obtained from patients who were from Asia, Africa, and Western and Eastern Europe).

\section{Dynamic Range and Reproducibility of Quantification from Serum Samples}

Clinical samples were serially diluted with normal human serum to assess the dependence of the quantitative result on the amount of virus in serum and to determine the sensitivity and dynamic range for quantification. As shown by an example in Figure 5A, the quantitative results were correctly dependent on virus concentration over up to five orders of magnitude. On the basis of the titer determined by the AffiProbe HepB test, ${ }^{(23)}$ the dynamic range shown in Figure $5 \mathrm{~A}$ was from 15 to $1.5 \times 10^{6}$ viral genome templates in $10 \mu \mathrm{l}$ of serum. Other clinical samples also gave similar curves. Thus, it can be concluded that the test is quantitative in a range of five orders of magnitudes.

The most sensitive range of the method was studied in more detail using the Eurohep reference specimen at our disposal. Its HBV DNA content had been determined to be $10^{9}$ Eurohep U/ml, with 1 Eurohep unit being 1-5 HBV DNA molecules. ${ }^{(21)}$ By our quantitative AffiProbe HepB test, ${ }^{(23)}$ its HBV DNA titer was $10^{9}$ molecules $/ \mathrm{ml}$. The specimen was serially diluted with HBV-negative serum and these dilutions were subjected to the quantitative PCR test. Figure 5B shows that the test was capable of quantifying 16 viral genomes $/ 10 \mu \mathrm{l}$ of serum. The titer of the undiluted Eurohep sample, determined from the dilution
( $\left.1: 2 \times 10^{6}\right)$ by using the standard curve was $1.4 \times 10^{9} / \mathrm{ml}$ (Fig. 5B).

The reproducibility of the quantitative PCR test was good, taking into account the dynamic range. When four clinical samples with titers $10^{4}-10^{6} \mathrm{HBV} /$ $\mathrm{ml}$ were pretreated and quantified four times, the titers obtained had a $\mathrm{CV}$ percent of $\sim 20 \%$ and maximally threefold differences could be detected (data not shown). Variation caused by the amplification reaction gave rise to no more than twofold differences in the titer, showing that a single amplification reaction from each sample was sufficient. The reproducibility of the test in the most sensitive region of the assay is shown in Table 2, where clinical samples containing very low quantities of virus $\left(2.8 \times 10^{3}-9 \times 10^{4} \mathrm{HBV} / \mathrm{ml}\right)$ were analyzed. Control serum gave extremely low signals irrespective of sample quantity, whereas the signals from viral samples responded to the quantity applied to PCR. Thus, volumes corresponding to at least $40 \mu \mathrm{l}$ of serum could be subjected to PCR to increase the sensitivity and reliability of the assay. The quantitative results obtained were highly reproducible even at the lowest end of the dynamic range.

\section{DISCUSSION}

The PCR test enables accurate quantifi-
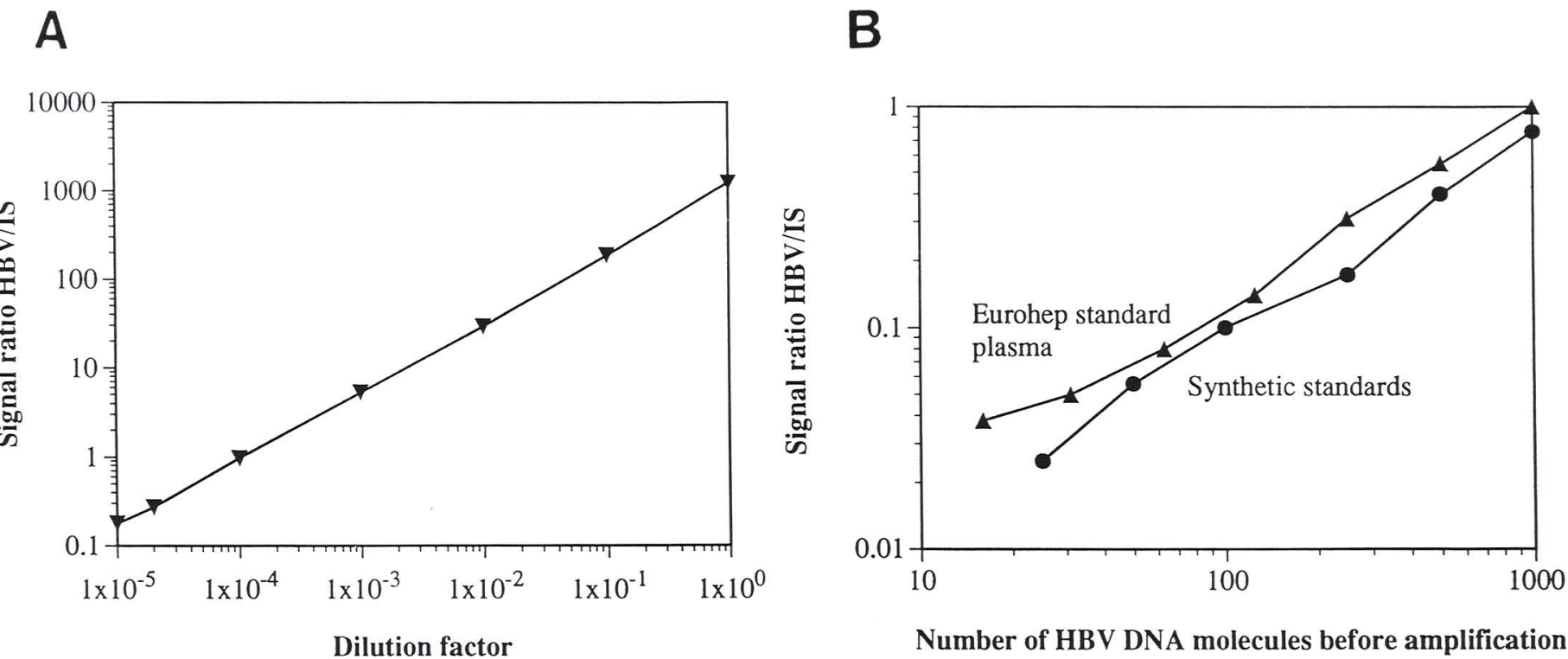

FIGURE 5 The dynamic range and sensitivity of the quantitative test for clinical samples. $(A)$ A clinical serum sample was serially diluted to negative control serum. The titer of the undiluted sample was $1.5 \times 10^{9} \mathrm{HBV} \mathrm{DNA} / \mathrm{ml}$ in the AffiProbe assay, and the volume applied to the PCR reaction corresponded to $10 \mu \mathrm{l}$. $(B)$ Sensitivity of the PCR quantification as analyzed with the Eurohep standard plasma $(\boldsymbol{\Delta})$, serially diluted to negative control serum. The number of synthetic HBV and IS standard molecules (O) applied to PCR is based on concentration determination of the stock solutions. The number of molecules shown for the dilution series of the Eurohep sample are calculated from the AffiProbe titer $\left(1 \times 10^{9} \mathrm{HBV}\right.$ $\mathrm{DNA} / \mathrm{ml}$ ) of undiluted sample. (The cutoff for the lowest positive measurement was determined as follows: Both the HBV signal and HBV/IS signal ratio of the sample were at least twofold as compared with those from control serum.) 
TABLE 2 Reproducibility of the Quantification from Clinical Specimens: Response to Sample Quantity

\begin{tabular}{|c|c|c|c|c|c|}
\hline \multirow{2}{*}{$\begin{array}{l}\text { Serum } \\
\text { sample }^{\mathbf{a}}\end{array}$} & \multicolumn{2}{|c|}{$A_{405} \times 10^{3}$} & \multirow{2}{*}{$\begin{array}{l}\text { Ratio } \\
\text { (HBV/IS) }\end{array}$} & \multirow[b]{2}{*}{ Quantity $^{\mathrm{b}}$} & \multirow{2}{*}{$\begin{array}{l}\text { Titer } \\
\text { (molecules/ml) }\end{array}$} \\
\hline & HBV & IS & & & \\
\hline $0-10$ & 7 & 675 & 0.01 & - & - \\
\hline $0-20$ & 6 & 813 & 0.01 & - & - \\
\hline $0-40$ & 8 & 634 & 0.01 & - & - \\
\hline $\mathrm{I}-10$ & 40 & 596 & 0.07 & 70 & $7 \times 10^{3}$ \\
\hline $\mathrm{I}-20$ & 124 & 972 & 0.13 & 130 & $6.5 \times 10^{3}$ \\
\hline I-40 & 187 & 735 & 0.25 & 260 & $6.5 \times 10^{3}$ \\
\hline II-10 & 28 & 512 & 0.05 & 40 & $4 \times 10^{3}$ \\
\hline II-20 & 46 & 801 & 0.06 & 60 & $3 \times 10^{3}$ \\
\hline II-40 & 85 & 750 & 0.11 & 110 & $2.8 \times 10^{3}$ \\
\hline III-10 & 68 & 574 & 0.12 & 100 & $1 \times 10^{4}$ \\
\hline III-20 & 197 & 716 & 0.28 & 290 & $1.5 \times 10^{4}$ \\
\hline III-40 & 413 & 628 & 0.66 & 700 & $1.8 \times 10^{4}$ \\
\hline IV-20 & 1070 & 698 & 1.53 & $1.8 \times 10^{3}$ & $9 \times 10^{4}$ \\
\hline IV-40 & 1380 & 640 & 2.2 & $2.9 \times 10^{3}$ & $7.3 \times 10^{4}$ \\
\hline
\end{tabular}

${ }^{a}$ Ten microliters (first experiment) or 20 and $40 \mu$ l (second experiment) of the clinical samples I-IV and the HBV-negative 0 control serum sample were pretreated and subjected to amplification.

${ }^{\mathrm{b}}$ The ratio of the measured absorbance values was calculated and the quantity interpreted from the respective standard curve.

cation of HBV DNA from samples containing amounts of virus too low for conventional quantitative assays. The test is easy to perform and is well suited for research use and routine clinical diagnostics. The post-PCR steps are carried out on microtiter plates rapidly, with low coefficient of variation, and with enlargened dynamic range of colorimetric measurement. Amplified DNAs can be quantified in $<2 \mathrm{hr}$.

The quantitative analysis of competitive PCR reactions typically has been tedious so far, with separation of the two products by electrophoretic techniques or HPLC. ${ }^{(1,6,8,20)}$ In most cases, quantification has been performed with isotopic label. Moreover, the competitive amplification is tedious when multiple PCR reactions are performed to titrate one sample with IS. ${ }^{(2,4-8,22)}$ In the present test, a single amplification is sufficient; therefore, several samples can be analyzed in one experiment. No tedious separation is necessary to quantify the amplified products. The nonradioactive detection system permits adequate and sensitive quantification, whereas the nonisotopic detection systems described previously for HBV DNA were used for qualitative assays only. ${ }^{(24,25)}$

The IS template of the present assay was synthetic, 104-bp long, and 80\% identical to the HBV DNA amplified. The assay was also completely functional, however, with a nonhomologous IS (amplification system 2), indicating that there are several choices for a suitable IS DNA.

When different quantitative tests are compared, it is of interest to analyze their standardization and evaluate how close the results are to the absolute titers. The Eurohep reference plasma $\left(1 \times 10^{9}\right.$ to $5 \times 10^{9} \mathrm{HBV} \mathrm{DNA} / \mathrm{ml}$ ) gave the result $1.4 \times 10^{9} \mathrm{HBV}$ DNA/ml in the PCR test and $1 \times 10^{9} \mathrm{HBV}$ DNA/ml in AffiProbe HepB. The other clinical specimens that could be tested by both assays showed on the average of 2.1-fold (s.D. 1.2) higher titers in the PCR assay as compared with the AffiProbe HepB. In the PCR test, during the very first cycles, mispriming was more possible theoretically from the $3.2-\mathrm{kb}$ genomic template than from the 104-bp-long HBV or IS templates. This could slightly overestimate the sample in the PCR test. The reference test AffiProbe, on the other hand, has a slightly underestimating standardization (vector sequences present both in standards and nick-translated probes). The conclusion is that all of the results were in good agreement and thus reliably quantified HBV DNA.

As in all PCR tests, contamination of unamplified samples with amplified material has to be prevented by standard precautions. The limitations caused by strain differences have been minimized by amplifying a well-conserved region and using the universal base inosine in primers and probes. The AffiProbe test with long probes and no amplification is not sensitive to strain differences, and none of the samples tested so far with the two tests have shown clearly test-dependent results.

With each step optimized and validated, the test offers a convenient new possibility for accurate monitoring of HBV DNA levels in serum and plasma samples in a large dynamic range. The present sensitivity is likely to be sufficient for quantitative monitoring of the virus in most clinical applications.

\section{ACKNOWLEDGMENTS}

We thank Ms. Auli Kähärä-Uppgård for performing most of the experimental work. We also wish to thank Dr. Lars Paulin for the synthesis of many primers and probes, Dr. Nisse Kalkkinen for help in their purification, Ms. Sini Heinonen for careful technical assistance, and Ms. Heini Järvi for help in preparing the manuscript. The Department of Virology, University of Helsinki, and The Finnish Red Cross, Helsinki, are acknowledged for providing the serum and plasma samples.

\section{REFERENCES}

1. Ferre, F. 1992. Quantitative or semi-quantitative PCR: Reality versus myth. $P C R$ Methods Applic. 2: 1-9.

2. Becker-André, M. and K. Hahlbrock. 1989. Absolute mRNA quantification using the polymerase chain reaction (PCR). A novel approach by PCR aided transcript titration assay (PATTY). Nucleic Acids Res. 17: 9437-9446.

3. Wang, A.M., M.V. Doyle, and D.F. Mark. 1989. Quantitation of mRNA by the polymerase chain reaction. Proc. Natl. Acad. Sci. 86: 9717-9721.

4. Gilliland, G., S. Perrin, K. Blanchard, and H.F. Bunn. 1990. Analysis of cytokine mRNA and DNA: Detection and quantitation by competitive polymerase chain reaction. Proc. Natl. Acad. Sci. 87: 27252729.

5. Lundeberg, J., J. Wahlberg, and M. Uhlén 1991. Rapid colorimetric quantification of PCR-amplified DNA. BioTechniques 10: $68-75$.

6. Menzo, S., P. Bagnarelli, M. Giacca, A. Manzin, P.E. Varaldo, and M. Clementi. 1992. Absolute quantitation of viremia in human immunodeficiency virus infection by competitive reverse transcription 
and polymerase chain reaction. J. Clin. Microbiol. 30: 1752-1757.

7. Scadden, D.T., Z. Wang, and J.E. Groopman. 1992. Quantitation of plasma human immunodeficiency virus type 1 RNA by competitive polymerase chain reaction. J. Infect. Dis. 165: 1119-1123.

8. Piatak, M., M.S. Saag, L.C. Yang, S.J. Clark, J.C. Kappes, K.-C. Luk, B.H. Hahn, G.M. Shaw, and J.D. Lifson. 1993. High levels of HIV-1 in plasma during all stages of infection determined by competitive PCR. Science 259: 1749-1754.

9. Jalava, T., P. Lehtovaara, A. Kallio, M. Ranki, and H. Söderlund, H. 1993. Quantification of hepatitis B virus DNA by competitive amplification and hybridization on microtiter plates. BioTechniques 15: $1-5$.

10. Kaneko, S., R.H. Miller, S.M. Feinstone, M. Unoura, K. Kobayashi, N. Hattori, and R.H. Purcell. 1989. Detection of serum hepatitis B virus DNA in patients with chronic hepatitis using the polymerase chain reaction assay. Proc. Natl. Acad. Sci. 86: 312-316.

11. Zeldis, J.B., J.H. Lee, D. Mamish, D.J. Finegold, R. Sircar, Q. Ling, P.J. Knudsen, I.K. Kuramoto, and L.T. Mimms. 1989. Direct method for detecting small quantities of hepatitis B virus DNA in serum and plasma using the polymerase chain reaction. J. Clin. Invest. 84: 1503-1508.

12. Gerken, G., P. Paterlini, M. Manns, C. Housset, S. Terre, H.-P. Dienes, G. Hess, W.H. Gerlich, P. Berthelot, K.-H. Meyer zum Buschenfelde, and C. Brechot. 1991. Assay of hepatitis B virus DNA by polymerase chain reaction and its relationship to pre-S and S-encoded viral surface antigens. Hepatology 13: 158-166.

13. Escarceller, M., F. Rodriguez-Frias, R. Jardi, B. San Segundo, and R. Eritja. 1992. Detection of hepatitis B virus DNA in human serum samples: use of digoxigeninlabeled oligonucleotides as modified primers for the polymerase chain reaction. Anal. Biochem. 206: 36-42.

14. Ulrich, P.P., R.A. Bhat, B. Seto, D. Mack, J. Sninsky, and G.N. Vyas. 1989. Enzymatic amplification of hepatitis B virus DNA in serum compared with infectivity testing in chimpanzees. J. Infect. Dis. 160: 37-43.

15. Brunetto, M.R., F. Oliveri, G. Rocca, D. Criscuolo, E. Chiaberge, M. Capalbo, E. David, G. Verme, and F. Bonino. 1989. Natural course and response to interferon of chronic hepatitis B accompanied by antibody to hepatitis B e antigen. Hepatology 10: 198-202.

16. Saracco, G., G. Mazzella, F. Rosina, C. Cancellieri, V. Lattore, E. Raise, G. Rocca, L. Giorda, G. Verme, G. Casbarrini, L. Barbara, F. Bonino, M. Rizzetto, and E. Roda. 1989. A controlled trial of human lymphoblastoid interferon in chronic hepatitis B in Italy. Hepatology 10: 336-341.
17. Perillo, R., R. Schiff, G. Davis, H. Bodenheimer, K. Lindsay, J. Payne, J. Dienstag, C. O'Brien, C. Tamburro, I. Jacobson, R. Sampliner, D. Feit, J. Lefkowitch, M. Kuhns, C. Meschievitz, B. Sanghvi, J. Albrecht, A. Gibas, and the Hepatitis Interventional Therapy Group. 1990. A randomized, controlled trial of interferon alpha-2b alone and after prednisone withdrawal for the treatment of chronic hepatitis B. N. Engl. J. Med. 323: 295-301.

18. Iizuka, H., K. Ohmura, A. Ishijima, K. Satoh, T. Tanaka, F. Tsuda, H. Okamoto, Y. Miyakawa, and M. Mayumi. 1992. Correlation between anti-HBc titers and HBV DNA in blood units without detectable HBsAg. Vox Sang. 63: 107-111.

19. Bichko, V., P. Pushko, D. Dreilina, P. Pumpen, and E. Gren. 1985. Subtype ayw variant of hepatitis B virus. DNA primary structure analysis. FEBS Lett. 185: 208212.

20. Liang, T.J., K.J. Isselbacher, and J.R. Wands. 1989. Rapid identification of low level hepatitis B-related viral genome in serum. J. Clin. Invest. 84: 1367-1371.

21. Gerlich, W.H., K.-H. Heermann, and R. Thomssen. 1993. Eurohep trial for generation of reference samples for hepatitis B virus DNA. Seventh Eurohep Workshop, Paris, France.

22. Lin, J.H-C., B. Grandchamp, and N.G. Abraham. 1991. Quantitation of human erythroid-specific porphobilinogen deaminase mRNA by the polymerase chain reaction. Exp. Hematol. 19: 817-822.

23. Jalava, T., M. Ranki, M. Bengtström, P. Pohjanpelto, and A. Kallio. 1992. A rapid and quantitative solution hybridization method for HBV DNA in serum. J. Virol. Methods 36: 171-180.

24. Valentine-Thon, E., J. Steinmann, and W. Arnold. 1991. Detection of hepatitis B virus DNA in serum with nucleic acid probes labelled with ${ }^{32} \mathrm{P}$, biotin, alkaline phosphatase or sulphone. Mol. Cell. Probes 5: 299-305.

25. Yang, G., P.P. Ulrich, R.A. Aiyer, B.D. Rawal, and G.N. Vyas. 1993. Detection of hepatitis B virus in plasma using flow cytometric analyses of polymerase chain reaction-amplified DNA incorporating digoxigenin-11-dUTP. Blood 81: 10831088 .

Received July 2, 1993; accepted in revised form September 24, 1993. 


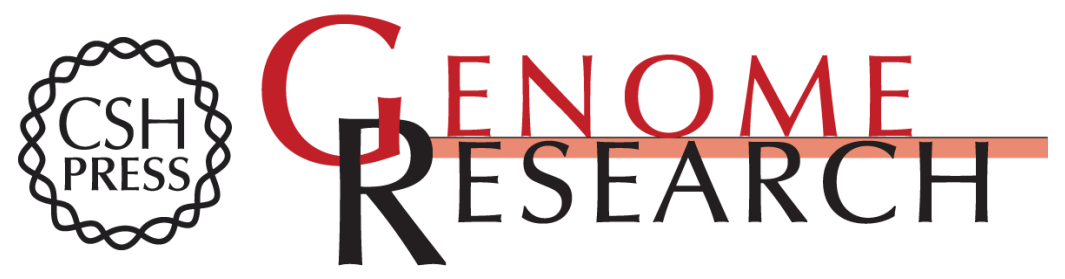

\section{Quantitative PCR for hepatitis B virus with colorimetric detection.}

P Lehtovaara, M Uusi-Oukari, P Buchert, et al.

Genome Res. 1993 3: 169-175

References This article cites 24 articles, 6 of which can be accessed free at:

http://genome.cshlp.org/content/3/3/169.full.html\#ref-list-1

\section{License}

Email Alerting Receive free email alerts when new articles cite this article - sign up in the box at the Service top right corner of the article or click here.

\section{Affordable, Accurate Sequencing.}

To subscribe to Genome Research go to: https://genome.cshlp.org/subscriptions 